\title{
Ssciendo
}

Ethics \& Bioethics (in Central Europe), 2020, 10 (3-4), 190-202

DOI:10.2478/ebce-2020-0018

\section{What is critical in the Anthropocene? A discussion of four conceptual problems from the environmental-political philosophy perspective}

\author{
Daniel Buschmann ${ }^{1}$
}

\begin{abstract}
The Anthropocene confronts environmental philosophy with one of the most urgent questions of the $21^{\text {st }}$ century: How to maintain the earth's condition in a way that allows current and future human generations to thrive? By asking such a question, ethical thought ceases to be solely a matter of individuality or morality. Instead, it raises a political issue: How can or should environmental philosophy relate to society in the Anthropocene? This article argues for a critical perspective that draws on contemporary historic materialist scholars and politicises societal power relations. It exemplifies this approach by discussing key-terms of the Anthropocene discourse, like planetary boundaries, tipping points, and space-ship earth. The article concludes that the idea that "we have to act fast now" would be dangerously too easy because it ignores the ambivalent character of human-nature relations.
\end{abstract}

Keywords: Anthropocene, environmental philosophy, ethics, social theory, critical thought

\section{Introduction}

Disastrous consequences of human actions in the Anthropocene (Steffen et al., 2015a/b) urge modern environmental philosophy to discuss pressing bioethical questions (St'ahel, 2019; Randall, 2016; Sherwin, 2008; Naess, 1973). How can current and future human generations thrive without exploiting natural resources? ${ }^{2}$ How to justify ecological politics in the presence of social injustice? However, many traditional concepts in bioethics fall short of this challenge (Arras, 2016; Warren, 2015). This article suggests that insights of modern social theory are relevant to this debate and proposes developing a critical environmental-political-philosophical approach. In doing so, it highlights systematic problems in several key concepts of the Anthropocene debate.

Here, to understand the relevance of social theory for bioethical questions, we must accept the premise that the environmental question is a political one. Referring to Richard Stahel, a key researcher in Central Eastern European debate, philosophical considerations about the environment are "the central theme or even the basic assumptions of all thinking about politics and society" (St'ahel, 2019, p. 349). Furthermore, he states that the sustainable "care for the polis [...] is one of the main reasons for philosophy's existence" (St'ahel, 2017, p. 446). These statements highlight that philosophical issues concerning the natural environment or society apparently separate topics at first glance - are actually deeply intertwined. Thus, we encounter a political question: How exactly can the polis be sustainable?

This is where the normative notion of critical environmental-political philosophy ${ }^{3}$ is rooted. The latest that the term biopower, or biopolitics, appeared first was in Michel Foucault's works in 1978 (Foucault, 2006, p. 42) the discipline of bioethics ceased to be solely a matter of individuality or morality. By politicising "domination at every level and in every form" (Foucault, 2000, p. 281), social theory entered the discourse of how the polis shall interact with

\footnotetext{
${ }^{1}$ Environment Agency Austria, Vienna; daniel.buschmann@umweltbundesamt.at

${ }^{2}$ Clearly, human life cannot thrive without non-human life flourishing as well. This article, however, will put a focus on the societal dimensions of the Anthropocene; therefore, it is beyond its scope to deepen the aspects of non-human life.

${ }^{3}$ In the following I speak of environmental-political philosophy in order to acknowledge that both aspects need to be discussed with regard to their complex interconnectedness.
} 
life. A critical environmental-political philosophy in this context is an attempt to relate the ethical, and often individualistic, considerations of 'how shall we act' with a tradition of critical thought, that is, societal theory developed by, inter alia, Foucault in respect of works by Hegel, Marx, the Frankfurt School and others (Foucault, 2010, p. 21). Thus, the adjective critical means to positively acknowledge a history of social struggles that politicise distributional inequality, the violent exercise of power, and exclusion of people from freedom, wealth or human rights. Critical philosophical considerations are transparent about their normative bias, insofar as they reject these forms of domination and strive for a less exclusive organization of society. The reason for making this transparent is that normative biases affects all research but often remain undisclosed in order to maintain the illusion of scientific objectivity (Reiss \& Sprenger, 2014, 2.2).

Why, it might be asked, is a critical environmental-political philosophy needed and what added value does it provide? This is because most existing theories (e.g. metaphysical, critical: Arras, 2016; rationalism, critical: Warren, 2015) do not capture the complex relations between global problems and local conflicts (Stahel, 2020, p. 3). Individual ethics, for example, is an insufficient tool to understand global societal issues (Stahel, 2020, p. 5f.). This is firstly because environmental effects are beyond the scope of individual action, and secondly because any individual perspective conceals the structural power relations in society. Thus, the value of social theory is "to make harder those acts which are now too easy" (Foucault, 1988, p. 155), meaning to reject any fast solutions that disregard the societal roots beneath seemingly external environmental issues. However, making it harder to discuss the Anthropocene is not a philosophical Glass Bead Game, but an endeavour to prevent dangerous societal and environmental backlashes resulting from too easy solutions.

In the following, this article will illustrate the need for critical environmental-political philosophy in more detail by referring to the Anthropocene debate and a couple of its key concepts. Chapter 2 therefore discusses the idea of a homogeneous anthropos, the ambivalent role of science-policy interfaces, the shortcomings of the planetary boundaries concept, and finally the relevance of social justice. Chapter 3 briefly wraps up the cornerstones of the argumentation and draws conclusions.

\section{What is critical in the Anthropocene?}

The term Anthropocene originates from a discourse among geologists who divide the earth's history into separate ages, or eras, each named after a dominant stratigraphic element that can be found in sediments all around the world. The consensus is that during the Pleistocene (2.6 million years ago until 12 thousand years ago) the ice was the major, telluric force, shaping the face of the earth. It is followed by the Holocene (starting 12 thousand years ago), where warmth and, thus, melting ice was characteristic. However, since the $19^{\text {th }}$ century, this consensus is increasingly often challenged by geologists who argue that, nowadays, humans are the major, telluric force that shapes the face of earth, calling this new era the Anthropocene. It is still contested when exactly this era began (Lewis \& Maslin, 2015) - with the triumph of agriculture about 10 thousand years ago, with industrialization and climate change since the $1870 \mathrm{~s}$, or with the global spread of radioactive isotopes that stem from nuclear bomb tests in the 1960s? Either way, the debate experienced global attention in 2002 when Nobel-prize winner Paul Crutzen (re-)introduced the term Anthropocene in Nature (Crutzen, 2002), and later linking it with the notion of a great acceleration (Steffen et al., 2015b) of resource use and pollution across all sectors, scales, and regions since the 1960s.

One reason why the term Anthropocene became so popular is because it is a boundary concept at the edge between science and politics. The term conveys two clear messages: Firstly, that the accumulated consequences of human actions have led to a global change that undermines the stable preconditions of human life, once guaranteed during the Holocene. 
Secondly, as a consequence of this development, nature is no longer purely external to humans but needs to become the object of responsible human regulation, i.e. a global environmental governance (Biermann, 2014). In the following, the article examines four reasons why a critical environmental-political philosophy needs to intervene in this discussion.

\subsection{Disenchant the "anthropos"}

As much as the term Anthropocene helped to highlight the urgency of environmental issues, and positively politicised how much we all depend on nature as our material basis of life, it also obscures two essential aspects. Humans are neither the cause nor the solution of environmental issues. What does this mean?

First of all, the general notion of anthropos as the cause of the Anthropocene conceals that it neither was nor is humankind as such who continues to enforce environmental degradation. Within this heterogeneous group of actors some play a more significant role than others. People in the global North historically had and still have a higher impact on environmental changes, while being less vulnerable to its effects (O'Brien et al., 2007). Even within the global North or South, people with political or economic power have a higher impact on environmental changes than the ones without (Wissen, 2012), and also gendered differences exist (Alston \& Whittenbury, 2013). Even more importantly, the collectivization of all actors inside anthropos neglects the fact that they continue to pursue and protect different interests. Actors in the automobile industry for example, who want to secure their markets and business-models, seek alliances with government actors, who want to secure employment in order to be re-elected. By obscuring these significant differences between actors, the abstract anthropos obscures those who speak about whom and with which interests.

Secondly, who is addressed by the Anthropocene debate? Who can take the required actions? Is it the established institutions of global environmental governance? Is it national parliaments? Referring to anthropos in this context is highly ambivalent, as it ignores that exactly these actors failed to establish effective sustainable policies for already more than 40 years (Blühdorn, 2013; Brand \& Wissen, 2013). While isolated environmental issues like the ozone-layer or acid rain could be solved with the help of cheap supplements in production or general economic modernization (WBGU, 2011, p. 101), the general tendencies of a "great acceleration" in resource use and pollution continued to grow exponentially (Steffen et al., 2015a; 2015b). Thus, using the term Anthropocene to urge the established actors for action is, in the best case, an appeal to continue structurally ineffective measures in environmental governance, and, in the worst case, like putting a fox in charge of the henhouse (Brand \& Wissen, 2013). Transnational corporations with high environmental impact have since the 1990s found ways to protect their interests from too ambitious regulations, and institutions of global (environmental) governance have subordinated their goals to the "factual constrains" of economic growth and liberal market policies. A call for "more" or "faster" action towards these actors is likely to reproduce an array of shortcomings, unfavourable side-effects, and even failures that have characterized environmental governance since 1972 (The limits to growth), 1986 (Brundtland Report), 1992 ( $1{ }^{\text {st }}$ COP in Rio de Janeiro), 2005 (Kyoto-Protocol), and 2015 (Paris Agreement, Agenda 2030). None of these milestones of global environmental governance had even a slight impact on the great acceleration (Steffen et al., 2015b; Blühdorn, 2013; Brand \& Wissen, 2013; Brand \& Wissen, 2012), so why should an intensified pursuit of this path be successful?

Consequently, the anthropos as such can neither be used as a reference to the causation, nor as a reference to the solution of environmental issues. As Lövbrand et al. (2015) note, the anthropos in the Anthropocene is currently understood as post-natural, post-social, and postpolitical. This means (a) that nature is no longer perceived as purely external to society, but as one of their most crucial issues (= post-natural), (b) that humanity is perceived as a single, undistinguishable actor with uncontested common interests (=post-social), and (c) that politics 
is no longer a matter of balancing interests and weighting alternatives, but of taking scientifically clearly defined steps that result in survival if followed or catastrophe if ignored (=post-political). Following this critique, it is not "humankind" but a complex web of relations between society and its perceived environment that should be investigated as the cause of or solution to the Anthropocene. Such an understanding of societal nature relations embraces dialectical thought (Görg, 2011), and opens space to think of approaches and solutions which do not reproduce the structural social and environmental injustices that today display key challenges in environmental governance (Brand \& Wissen, 2013; Brand \& Wissen, 2012).

Thus, a greater degree of nuance and complexity is necessary, and a critical environmentalpolitical philosophy is in charge to reflect upon it. What is the role of (global) environmental governance in society? How do contested societal interests materialize in (environmental) public policy? In what ways are societies and their natural environments entangled? Who has the agency to act in the Anthropocene, on which legitimatory basis, in whose interest, and for which ends? Talking about "humanity" in general bears the risk of falling short of the complexity of the challenges posed by the Anthropocene, and therefore failing to provide the answers needed so urgently.

\subsection{Debunk objective science and politics}

In its role as a boundary concept at the edge of environmental science and politics, the term Anthropocene is often associated with the idea that "science speaks truth to power" (Ortiz, 2019). ${ }^{4}$ In other words, concerned natural scientists reveal objective facts about the status of the external environment to political decision makers in order to give them a solid basis for their responsible decision-making. The following sections demonstrate why this popular image is at best wishful thinking. Neither do scientists possess "the truth" nor do the addressed decision-makers possess "the power" or have their interests exclusively in sustainability. Even under the premise that the abovementioned expression is meant as a metaphor, environmentalpolitical philosophy needs to reflect critically on the ideal relationship between science and society this approach suggests.

Firstly, let alone the fact that there is nothing like "the science", the idea that science could be objective or deliver objective insights is fundamentally problematic (Mulder, 2020; Reiss \& Sprenger, 2014). In being subjects, scientists always have normative assumptions about the world, i.e. ideological frameworks, selective research interests, and political views. This influences research agendas and to some degree also the outcomes of research. Already, in 1904, Max Weber notes: "There is no absolutely objective scientific analysis of [...] 'social phenomena' independent of special and 'one-sided' viewpoints according to which expressly or tacitly, consciously or unconsciously they are selected, analyzed and organized for expository purposes" (Weber, 1949, p. 72). This said, Weber does not imply that scientific insights are purely subjective either (Weber, 1949, p. 84). Scientific insights can be significant and meaningful for a wide audience if communicated in a well-balanced way, through a valueneutral language, by applying a falsifiable methodology, or a logical line of argumentation. Still, scientific objectivity remains an unattainable, highly ambivalent ideal (Mulder, 2020; Grasswick, 2018). Ambivalent in so far as the idea of one objective, universal truth often reproduces colonial, sexual, etc., power relations and discursive exclusions (Anderson, 2020; Escobar, 2016). This fact needs to be critically considered when demanding that the science shall speak the truth to the power in the Anthropocene.

Consequently, rather than trying to appear objective and therefore implicitly claiming unjustified authority (Grosfoguel, 2007), critical environmental-political philosophy should act openly with its implicit biases, prepositions, and goals. Since the science is not able to speak

\footnotetext{
${ }^{4}$ See also: https://www.unitebehindthescience.online/
} 
the truth, scientific knowledge does not deserve privilege in the political discourse. A dialogue between science and society can therefore only work on eye-level, in mutual appreciation, not based on "non-negotiable limits" (Steffen et al., 2011) posed by science. Scientific investigation, moreover, can, as diverse and heterogeneous as the science is, learn a lot from non-academic, non-western, non-hegemonial forms of knowledge through transdisciplinary research methods (Shilliam, 2011; Grosfoguel, 2007; O’Brien et al., 2007; Harvey, 1993). Rather than speaking truth about society or towards decision-makers, the role of critical scientific approaches is collaboration together with and in appreciation of other knowledge producers, while acting openly with its own normative biases and limitations.

Secondly, the politics is neither a single actor nor a neutral decision-making tool. While many (mostly natural) scientists dream of addressing "the power", meaning "the politics" or "the national decision-makers" with their expertise (e.g. WBGU, 2011, p. 188, NEAA, 2009, p. 5 ), it must be remembered that national states cannot automatically be considered as neural actors. A state, understood as a material condensation of power relations (Brand \& Wissen, 2013; Kannankulam, 2008), is a contested territory where different interests struggle to become hegemonic (Brand \& Wissen, 2015). Accordingly, a state is a complex conglomerate of actors with a heterogeneous set of interests that might align with environmental causes or not. Therefore, national states cannot simply be perceived as neutral problem-solving tools to put scientific knowledge into action, but as complex material and discursive structures that represent and protect complex constellations of interests. Why does this matter? Because the historic shortcomings of national states in dealing with environmental issues have structural explanations (Brand \& Wissen, 2013) that cannot be ignored. Or, in the oversimplified words of Terry Eagleton (2006): "power knows the truth already, and is busy concealing it". As a result, critical environmental-political philosophy needs to be careful with ascribing agency in environmental issues to "the politics". Some investigations suggest that also international organizations can be understood as a material condensation of power relations (Brand \& Wissen, 2012; Brand, 2009). This would mean that rather than overcoming the shortcomings of national states regarding environmental regulation, international organizations in their current shape could reproduce them. Critical environmental-political philosophy, therefore, needs to politicise who is urged to action and under which conditions, meaning in which political processes with whose participation or exclusion, actions are supposed to be realized. Otherwise, overly enthusiastic natural scientists might appeal to the political fox for more responsible henhouse management.

\subsection{Abandon space-ship earth (and planetary boundaries)}

The metaphor most frequently associated with the Anthropocene is "spaceship earth" (Crutzen et al., 2011; critical: Höhler, 2015). The narrative dates back into the 1960s and points towards the vulnerability of "our small blue planet" (WBCSD, 2010, p. 2) as well as to a technologically advanced drive for research and discovery. It therefore appeals to a global spirit of responsibility and world-citizenship. Strongly liked with this metaphor are the idea of planetary boundaries (Rockström et al., 2009; critical: Geden \& Beck, 2014) and tipping points (Steffen et al., 2015a), which are therefore also discussed in this context. ${ }^{5}$ While spaceship-earthmetaphors are often used to highlight the urgency of environmental politics, they involuntarily convey many problematic messages. In the following, they are discussed among the three analytical axes of (a) humans, (b) nature, and (c) the human conquest of nature.

\section{(a) Humans}

Similar to the way anthropos blurs who causes and who suffers from environmental issues (see

\footnotetext{
${ }^{5}$ The website anthropocene.info mentions both terms as key elements: http://www.anthropocene.info/
} 
2.1), the spaceship-earth-metaphor merges all humans into a single political subject - with one seemingly homogeneous interest: to survive. This is problematic for several reasons among which four are important: Firstly, the spaceship-metaphor implicitly calls for a captain, for someone who is "in command" and decides about the rules everyone else has to follow. Stereotypically, one would imagine a white, old, heterosexual male with military experience to be the captain. In other words, the prerogative of a global environmental crisis implicitly calls for traditional authoritative leadership to ensure the greater common good. This call is highly ambivalent, not only because such kind of power bears a veritable potential for misuse or because it reproduces exclusive power relations, but mostly because it ranks democratic processes of careful negotiation between interests, and participatory, nuanced decision-making as useless in environmental matters. Moreover, differently to a captain, who qualifies for his position mostly through advanced commanding experience and power in a superior hierarchical context, no current institution of global governance has a comparable legitimation to rule over all of humanity. Consequently, established institutions are called to bring spaceship earth back on course - a questionable call, considering their (systematic) failure in the past 40 years of environmental politics (see 2.1, 2.2; Blühdorn, 2013; Brand \& Wissen, 2013; Brand \& Wissen, 2012). Calling upon this authority might therefore, against all good intentions, result in accelerating the environmental crisis or at least prolonging it.

Secondly, the spaceship-earth metaphor depoliticises environmental policy as a factual constraint. Decision-making based upon "non-negotiable limits" (Steffen et al., 2011) is a problematic approach to democracy, the very idea of which is to balance powers and interests and hence negotiates between different actors, interests, and positions. Where is the political in the context of humanity as a single subject with homogeneous interests? Thirdly, exactly these unequal powers and interests are concealed in the spaceship-metaphor. It levels significant differences between e.g. the global North and South, classes, ethnicities, and genders (ArroraJonsson, 2011; Dankelman, 2010; Hartcourt \& Escobar, 2005) concerning their agency in causation of environmental crises, and their vulnerability to its effects (Alston \& Whittenburg, 2013; Nightingale, 2011). In other words: "distinctions between hotel room cleaners and hedge fund managers become irrelevant” (Lohmann, 2014, p. 1).

Lastly, the spaceship-metaphor displays a cybernetic hubris. When biophysical parameters of the earth become the object of human actions, critical environmental-political philosophy needs to ask who (democratic parliaments?) governs over what (external nature?) to which ends (sustainable economic growth?) and in whose interest? Without these questions asked, the reference to spaceship earth could legitimate radical but highly questionable cybernetic approaches like carbon capture and storage (critical: Evar et al., 2012; Meadowcroft \& Langhelle, 2009) or solar radiation management (critical: Wiertz, 2016; UBA, 2011), and problematic economic strategies like the Green new deal or Green economy (see EC, 2019; critical: Brand \& Wissen, 2015). Questioning the ends and the beneficiaries of these approaches should take priority over fast but half-baked solutions that might in the end fight the fire with more oil.

\section{(b) Nature}

Spaceship-earth-metaphors, as well as references to planetary boundaries, draw a specific image of "nature", as opposed to the "humans". While acknowledging the interconnectedness of multiple dimensions of natural change (e.g. global warming, ocean acidification, and biodiversity loss, see Rockström et al., 2009) in a systemic perspective, the imagination of nature in these concepts also raises some important questions that need to be discussed. Here, four interconnected aspects are central: Firstly, nature is stereotyped as external to humans (the single political subject) and potentially dangerous for their survival. Thus, and similar to the anthropos (see 2.1), nature appears as uniform and without regional specifications or 
differences. How, then, for example, does the loss of coral reefs in one region affect the resilience of ecosystems worldwide? In a false dichotomy (Görg, 2011), nature can either ensure human survival, like during the stable and comfortable Holocene, or risk human survival, like in the unstable and dangerous Anthropocene. In any case, nature appears as a "higher force", generally separated from the human world but manipulatable by human actions. If this premise of an external nature is accepted, then, secondly, the domination of nature for the sake of human survival appears to be not only logical but also legitimate. This justifies, for example, unlimited access to natural resources, and the cybernetic human control of natural systems through Green Governance mechanisms (critical: Brand \& Wissen, 2013) or questionable technological methods of Geoengineering (critical: Wiertz, 2016; UBA, 2011).

Thirdly, justice in this context appears as a quantifiable matter, as equally distributed rights to use the atmosphere as a dumpsite for, inter alia, greenhouse gases. Qualitative aspects of (in-) justice disappear in such a perspective (see 2.4). For example, the difference between luxury emissions and emissions to fulfil basic needs, specific differences in climate vulnerabilities (Alston \& Whittenbury, 2013) or different degrees of participation in climate political decision-making (Harvey, 1993). Lastly, quantifiable planetary boundaries falsely suggest scientific certainty (see 2.2, Geden \& Beck, 2014) in identifying absolute natural thresholds, which, when crossed, endanger human survival in general. This perspective on nature, however, obfuscates that different groups of humans are affected to different degrees by climate change, and that the thresholds for inhumane consequences vary between class, ethnicity, and gender (Nightingale, 2011). What appears to be a "safe operation space" (Rockström et al., 2009; Steffen et al., 2015a) for people in the global North, is currently already associated with large-scale fires, droughts, hunger or flooding in the global South. Thus, the concept of planetary boundaries neglects that the mere definition of seemingly objective global and universal "tipping points" is in fact a normative act (Höhler, 2015). Depicting unacceptable future change in the global North as "beyond the safe operation space", while at the same time ignoring the present human suffering in the global South, is per se a political and not a scientific decision (Geden \& Beck, 2014). Consequently, the planetary boundaries are socio-political, not external natural boundaries. This is not to say that the concept of planetary boundaries consequently ignores the existence of something like "societal boundaries" that could mark a safe "operation space for humanness", something like poverty, violence, hunger, or political persecution. A very first step in this direction can be seen in the discussion started by Otto et al. (2020).

\section{(c) The human conquest of nature as an act of survival}

Besides concealing crucial normative assumptions (see above) the concept of "tipping points", as one of the key elements of the Anthropocene discourse, needs to be discussed also under another perspective. The depiction of future "disastrous consequences for humans" (Rockström, 2009 , p. 472) as a result of overstepping tipping points, has two important implications when put under a critical environmental-political philosophy lens: Firstly, the disastrous status quo, i.e. global-scale exploitation of humans and nature (Demirovic et al., 2011) and current climatefuelled catastrophes in the Global South, appears as acceptable, or, if seen as a "safe operation space" (Rockström et al., 2009) even worth protecting. Consequently, the underlying societal relations that cause tipping points to be reached, remain invisible and untouched (Höhler, 2015; Hulme, 2008). Instead, neo-Malthusian ideas of cybernetic societal regulation appear to be a choice without alternatives (Köhler, 2016, p. 249). A debate that develops in such a direction favours short-term technical solutions that do not touch the substance of the problems they are supposed to address. Moreover, if the mere survival of human civilization is at stake, options of self-limitation or even publicly enforced limitation of individual freedom becomes a matter of discussion. All of this because of a focus on the environmental symptoms, not at the societal 
causes of "tipping points". This article therefore proposes a different focus: not on the survival of the human species, but on the survival of humaneness in society. This shift implies attention to fundamentally different questions: Which modes of development guarantee a good life for all (Görgen \& Wendt, 2020; O’Neill, 2018; Novy, 2017)? To what extent are current modes of development unjust (Wissen \& Brand, 2018)? And what positive trajectories of development can be envisaged (D'Alisa et al., 2014)?

Secondly, the implicit catastrophism ${ }^{6}$ transported by the idea of "tipping points" favours dystopian narratives (Buschmann \& Plank, 2020). Not only does this depoliticize the effects of global industrial pollution as an external natural force that comes as a divine punishment upon humanity (Hulme, 2008). In the subtext, radical measures are suggested that need considerable political authority to be enforced (Brand, 2016). The open discussion about the limits of democracy in the context of the Anthropocene (Hammond et al., 2020) can be a chance for progressive emancipatory reform of participation modes in public policy, but also a veritable threat to democratic virtues and liberties, and socio-environmental justice. Critical environmental-political philosophy in this context needs to discuss who is called by the appeal to act in the tipping points metaphor, what are the (implicitly) suggested actions, and how are they supposed to be enforced?

\subsection{Reconsider: Which justice?}

As a last critical intervention in the Anthropocene discourse, the idea of environmental justice needs to be reflected. Being a relatively young debate (Barritt et al., 2019), considerations of environmental justice face an important divide: qualitative versus quantitative concepts of justice (Brunnengräber \& Dietz, 2016, p. 160). In short, quantitative concepts discuss the equal distribution of the atmosphere as a greenhouse gas disposal site, while qualitative concepts focus on participatory decision-making processes in climate governance, and on developing different modes of production and consumption. Thus, qualitative concepts of environmental justice strongly link to issues of social justice, distributional equity, and discussions of a good life for all (O'Neill, 2018; Novy, 2017). They, thus, politicise current modes of development (Görgen \& Wendt, 2020) and often call for a democratization of societal nature relations (Wissen, 2016). Under this premise, it is crucial to include not only environmental, but also social, sexual, and racial aspects of justice, that often intersect in a web of mutually reinforcing relations (Walby et al., 2012). To sum up, rather than talking about environmental justice between nations or "humans", critical environmental-political philosophy needs to ask who can participate how in which processes (or not), and to which ends?

\section{Conclusion and prospects}

This article aimed at making it harder to discuss the Anthropocene by examining the societal roots beneath seemingly external environmental issues, intending thereby to prevent dangerous societal and environmental backlashes that might result from too easy solutions. In doing so, the article identified four main challenges.

Firstly to disenchant the anthropos, meaning to question whether "humanity" is the cause of or the solution to environmental issues in the Anthropocene. The article rejected both notions, criticising that anthropos is currently understood as post-natural, post-social, and post-political. Secondly, to debunk objective science and politics by questioning a science-policy interface that aims at "speaking truth to power". Here, scientists should acknowledge their normative biases and seek the exchange with non-scientific knowledge producers, while at the same time reflecting upon a 40-year history of failure in politics before uncritically urging it to action. Thirdly, metaphors of spaceship earth, tipping points or planetary boundaries should be

\footnotetext{
${ }^{6}$ This article focuses on the negative aspects of catastrophism. An in-depth discussion about possible positive aspects (Hrubec, 2019; Beck, 2015) is promising but beyond its scope.
} 
abandoned because they reproduce intolerable implications of humanity as a single political subject, and of nature as an object of regulation that threatens human survival. Thereby they play on catastrophism and fear, potentially giving leeway to authoritarian political solutions. Lastly, all these questionable implications contribute to blurring questions of social justice instead of opening up the debate about how decision-making processes about common goods should be, what are desirable societal goals (apart from survival), and how the needs of everyone can be satisfied in a sustainable manner.

Considering these critical interventions into the current Anthropocene debate, do we still have hope? Certainly, it is not the task of philosophy to be society's hope factory. Nevertheless, by disenchanting dystopian narratives, like "human civilization might collapse", "we have to act fast now", or "there is no alternative", we reclaim space for a discussion about how just and sustainable collective modes of developments could actually look. We generate new leeway in thinking of desirable societal alternatives beyond authoritarian rule, technological control or cemented inequalities. By making human-nature relations the object of discussion (rather than human survival), we have a chance to reflect and eventually dismantle the structural reasons for more than 40 years of relative failure in global environmental governance. Most of all, by critically problematizing the Anthropocene we can realize that "another world is possible", making it more likely to bring it about instead of fearfully protecting the illusionary security and comfort of the world we grew accustomed to.

\section{Acknowledgement}

This article is part of the VEGA project1/0291/18 Historic-philosophical analysis of environmental thinking, research on its influences on ethical, legal and political thinking and its social response.

\section{References}

ALSTON, M., \& WHITTENBURY, K. (2013): Research, action and policy: Addressing the gendered impacts of climate change. Dordrecht: Springer.

ANDERSON, E. (2020): Feminist epistemology and philosophy of science. In: Stanford Encyclopedia of Philosophy. [online] [Retrieved September 18, 2020] Available at: https://plato.stanford.edu/entries/feminism-epistemology/

ARORA-JONSSON, S. (2011): Virtue and vulnerability: Discourses on women, gender and climate change. In: Global Environmental Change, 21, pp. 744-751.

ARRAS, J. (2016): A taxonomy of theoretical work in Bioethics. In: E. N. Zalta (ed.): The Stanford Encyclopedia of Philosophy (Winter 2016 Edition). [online] [Retrieved September 20, 2020 Available at: https://plato.stanford.edu/entries/theory-bioethics/supplement.html

BARRITT, E., BOWMAN, M. \& DUVIC PAOLI, L. A. (eds.) (2019): Environmental justice in the Anthropocene. In: King's Law Journal, 30(2), pp. 173-329.

BECK, U. (2015): Emancipatory catastrophism: What does it mean to climate change and risk society? In: Current Sociology, 62(1), pp. 75-88.

BIERMANN, F. (2014): The Anthropocene: A governance perspective. In: The Anthropocene Review, 1(1), pp. 57-61.

BLÜHDORN, I. (2013): The governance of unsustainability: Ecology and democracy after the post-democratic turn. In: Environmental Politics, 22(1), pp. 16-36.

BRAND, U. (2016): 'Transformation' as a new critical orthodoxy: The strategic use of the term 'Transformation' does not prevent multiple crises. In: GAIA, 25(1), pp. 23-27.

BRAND, U. (2009): Staatstheorie und Staatsanalyse im globalen Kapitalismus. Ein ,neopoulantzianischer' Ansatz der IPÖ. In: E. Hartmann, C. Kunze, \& U. Brand (eds.): Globalisierung, Macht, Hegemonie. Münster: Westfälisches Dampfboot, pp. 212-241.

BRAND, U. \& WISSEN, M. (2015): Strategies of a Green Economy, contours of a Green 
Capitalism. In: K. van der Pijl (ed.): Handbook of the international political economy of production. Cheltenham UK: Edward Elgar, pp. 508-523.

BRAND, U. \& WISSEN, M. (2013): Crisis and continuity of capitalist society-nature relationships: The imperial mode of living and the limits to environmental governance. In: Review of International Political Economy, 20(4), pp. 687-711.

BRAND, U. \& WISSEN, M. (2012): Global environmental politics and the imperial mode of living: Articulations of state-capital relations in the multiple crisis. In: Globalizations, 9(4), pp. 547-560.

BRUNNENGRÄBER, A. \& DIETZ, K. (2016): Klimagerechtigkeit. In: S. Bauriedl (ed.): Wörterbuch Klimadebatte. Bielefeld: Transcript, pp. 157-162.

BUSCHMANN, D. \& PLANK, C. (2020): Dystopia for future? In: B. Görgen, B. \& B. Wendt (eds.): Sozial-ökologische Utopien: Diesseits oder jenseits von Wachstum und Kapitalismus? Munich: Oekom, pp. 97-114.

CRUTZEN, P. J., DAVIS, M. \& MASTRANDREA, M. D. (2011): Das Raumschiff Erde hat keinen Notausgang. Energie und Politik im Anthropozän. Berlin: Suhrkamp.

CRUTZEN, P. J. (2002): Geology of mankind. In: Nature, 451(6867), p. 23.

D'ALISA, G., DEMARIA, F. \& KALLIS, G. (2014): Degrowth: A Vocabulary for a new era. London: Routledge.

DANKELMANN, I. (2010): Gender and climate change: An Introduction. London: Routledge. DEMIROVIĆ, A., DÜCK, J., BECKER, F. \& BADER, P. (2011): VielfachKrise im finanzmarktdominierten Kapitalismus. Hamburg: VSA.

EAGLETON, T. (2006): The Truth Speakers. In: New Statesman, $3^{\text {rd }}$ April 2006. [online] [Retrieved September 15, 2020]. Available at: https://www.newstatesman.com/node/164028. EC (EUROPEAN COMMISSION) (2019): The European Green Deal. COM(2019) 640 final. Brussels, 11.12.2019. [online] [Retrieved September 12, 2020] Available at: https://ec.europa.eu/info/strategy/priorities-2019-2024/european-green-deal_en.

ESCOBAR, A. (2016): Thinking-feeling with the Earth: Territorial struggles and the ontological dimension of the epistemologies of the south. In: Revista de Antropología Iberoamericana, 11(1), pp. 11-32.

EVAR, B., ARMENI, C. \& SCOTT, V. (2012): An introduction to key developments and concepts in CCS: history, technology, economics and law. In: N. Markusson, S. Shackeley \& B. Evar (eds.): The social dynamics of carbon capture and storage: Understanding CCS representations, governance and innovation. London: Routledge, pp. 18-30.

FOUCAULT, M. (2008/2010): The government of self and others: Lectures at the Collège de France, 1982-1983. Houndmills \& New York: Palgrave Macmillan.

FOUCAULT, M. (1978/2006): Sicherheit, Territorium, Bevölkerung. Geschichte der Gouvernementalität I. Frankfurt a. M: Suhrkamp.

FOUCAULT, M. (2000): Ethics: Essential works of Michel Foucault, vol. 2, ed. P. Rabinow. London: Penguin.

FOUCAULT, M. (1988): Politics, philosophy, culture: Interviews and other writings, 19771984, ed. L. Kriztman. London: Routledge.

GEDEN, O. \& BECK, S. (2014): Renegotiating the global climate stabilization target. In: Nature Climate Change, 4(9), pp. 747-748.

GÖRG, C. (2011): Societal relationships with nature: A dialectical approach to environmental Politics. In: A. Biro (ed.): Critical ecologies: The Frankfurt school and contemporary environmental crisis. Toronto: University of Toronto Press, pp. 43-72.

GÖRGEN, B. \& WENDT, B. (2020): Sozial-ökologische Utopien: Diesseits oder jenseits von Wachstum und Kapitalismus? Munich: Oekom.

GRASSWICK, H. (2018): Feminist social epistemology. In: Stanford Encyclopedia of Philosophy. [online] [Retrieved August 16, 2020] https://plato.stanford.edu/entries/feminist- 
social-epistemology.

GROSFOGUEL, R. (2007): The epistemic decolonial urn. In: Cultural Studies, 21(2-3), pp. 211-223.

HAMMOND, M., DRYZEK, J. \& PICKERING, J. (2020): Democracy in the Anthropocene. In: Contemporary Political Theory, 19, pp. 127-141.

HARCOURT, W. \& ESCOBAR, A. (2005): Women and the politics of place. Bloomfield: Kumarian Press.

HARVEY, D. (1993): The nature of environment: The dialectics of social and environmental change. In: Socialist Register, 29, pp. 1-51.

HÖHLER, S. (2015): Spaceship Earth in the environmental age, 1960-1990. London: Pickering \& Chatto.

HRUBEC, M. (2019): Social or environmental conflicts or sustainable development? Positive Alarmism. In: Civitas, 19(2), pp. 281-295.

HULME, M. (2008): The conquering of climate: Discourses of fear and their dissolution. In: The Geographical Journal, 74(1), pp. 5-16.

KANNANKULAM, J. (2008): Autoritärer etatismus im neoliberalismus. Zur staatstheorie von Nicos Poulantzas. Hamburg: VSA.

KÖHLER, B. (2016): Raumschiff Erde. In: S. Bauriedl (ed.): Wörterbuch klimadebatte. Bielefeld: Transcript, pp. 245-252.

LEWIS, S. L. \& MASLIN, M. (2015): Defining the Athropocene. In: Nature, 519(7542), pp. 171-180.

LOHMANN, L. (2014): Fetishisms of apocalypse: The Corner House: Dorset. [online] [Retrieved August 6, 2020]. Available at: http://www.thecornerhouse.org.uk/sites/thecornerhouse.org.uk/files/Fetishisms\%20of\%20Apo calypse.pdf

LÖVBRAND, E., BECK, S., CHILVERS, J., FORSYTH, T., HEDRÉN, J., HULME, R., LIDSKOG, R. \& VASILEIADOU, E. (2015): Who speaks for the future of Earth? How critical social science can extend the conversation on the Anthropocene. In: Global Environmental Change, 32, pp. 211-218.

MEADOWCROFT, J. \& LANGHELLE, O. (2009): The politics and policy of carbon capture and storage. In: J. Meadowcroft \& O. Langhelle (eds.): Catching the carbon: The politics and policy of carbon capture and storage. Cheltenham \& Northampton: Edward Elgar, pp. 1-21.

MULDER, D. H. (2020): Objectivity. In: The Internet Encyclopedia of Philosophy. [online] [Retrieved September 10, 2020] Available at: https://iep.utm.edu/objectiv/

NAESS, A. (1973): The shallow and the deep, long-range ecology movement: A summary. In: Inquiry, 16(1), pp. 95-100.

NETHERLANDS ENVIRONMENTAL ASSESSMENT AGENCY (NEAA) (2009): Getting into the right lane for 2050. Bilthoven. [online] [Retrieved September 10, 2020] Available at: https://www.pbl.nl/en/publications/2009/Getting-into-the-Right-Lane-for-2050

NIGHTINGALE, A. J. (2011): Bounding difference: Intersectionality and the material production of gender, caste, class, and environment in Nepal. In: Geoforum, 42(2), pp. 153162.

NOVY, A. (2017): On the 'good life for all'. Vienna: Vienna University of Economics and Business. [online] [Retrieved September 10, 2020] Available at: http://www.guteslebenfueralle.org/en/about-gutes-leben-fuer-alle.html

O'BRIEN, K., ERIKSEN, S., NYGAARD, L. \& SCHJOLDEN, A. (2007): Why different interpretations of vulnerability matter in climate change discourses. In: Climate Policy, 7(1), pp. $73-88$.

O’NEILL, D. W., FANNING, A. L., LAMB, W. F. \& STEINBERGER, J. K. (2018): A good life for all within planetary boundaries. In: Nature Sustainability, 1, pp. 88-95. 
ORTIZ, E. (2019): Teen climate activist Greta Thunberg tells Congress: 'Unite behind the science'. In: NBC News, September 18 ${ }^{\text {th }}$ 2019. [online] [Retrieved September 10, 2020] Available at: https://www.nbcnews.com/science/environment/climate-activist-greta-thunbergtells-congress-unite-behind-science-n1055851

OTTO, I., DONGES, J. F., CREMADES, R., BHOWMIK, A., HEWITT, R. J., LUCHT, W., ROCKSTRÖM, J., ALLERBERGER, F., MCCAFFREY, F. M., DOE, S. S. P., LENFERNA, A., MORÁN, N., VAN VUUREN, D. P. \& SCHELLNHUBER, H. J. (2020): Social tipping dynamics for stabilizing Earth's climate by 2050. In: Proceedings of the National Academy of Sciences, 117(5), pp. 2354-2365.

RANDALL, T. E. (2016): Climate Justice: A Literary Review. In: International Journal of Feminist Approaches to Bioethics, 9(1), pp. 246-262.

REISS, J. \& SPRENGER, J. (2014): Scientific Objectivity. In: Stanford Encyclopedia of Philosophy. https://plato.stanford.edu/entries/scientific-objectivity

ROCKSTRÖM, J., STEFFEN, W., NOONE, K., PERSSON, A., STUART CHAPIN III, F., LAMBIN, E. F., LENTON, T. M., SCHEFFER, M., FOLKE, C., SCHELLNHUBER, H. J., NYKVIST, B., DE WIT, C. A., HUGHES, T., VAN DER LEEUW, S., RODHE, H., SÖRLIN, S., SYNDER, P. K., CONSTANZA, R., SVEDIN, U., FALKENMARK, M., KARLBERG, L., CORELL, R. W., FABRY, V. J., HANSEN, J., WALKER, J., LIVERMAN, D., RICHARDSON, K., CRUTZEN, P. \& FOLEY, J. A. (2009): A save operating space for humanity. In: Nature, 461(7623), pp. 472-475.

SHERWIN, S. (2008): Whither bioethics? How feminism can help reorient bioethics. In: International Journal of Feminist Approaches to Bioethics, 1(1), pp. 7-27.

SHILLIAM, R. (2011): International relations and non-western thought: Imperialism, colonialism and the investigations of global modernity. New York: Routledge.

SŤAHEL, R. (2020): Environmentalism as a political philosophy of the Anthropocene. Manuscript.

SŤAHEL, R. (2019): Sustainable development in the shadow of climate change. In: Civitas, 19(2), pp. 337-353.

STTAHEL, R. (2017): Self-Limitation as the basis of environmentally sustainable care of the self. In: Human Affairs, 27(4), pp. 444-454.

STEFFEN, W., RICHARDSON, K., ROCKSTRÖM, J., CORNELL, S. E., FETZER, I., BENNETT, E. B., BIGGS, R., CARPENTER, S. R., DE VRIES, W., DE WIT, C. A., FOLKE, C., GERTEN, D., HEINKE, J., MACE, G. M., PERSSON, L. M., RAMANATHAN, V., REYERS, B. \& SÖRLIN, S. (2015a): Planetary boundaries: Guiding human development on a changing planet. In: Science, 347(6223), pp. 736-747.

STEFFEN, W., BROADGATE, W., DEUTSCH, L., GAFFNEY, O. \& LUDWIG, C. (2015b): The trajectory of the Anthropocene: The great acceleration. In: The Anthropocene Review, 2(1), pp. 81-98.

STEFFEN, W., PERSSON, Å., DEUTSCH, L., ZALASIEWICZ, J., WILLIAMS, M., RICHARDSON, K., CRUMLEY, C., CRUTZEN, P., FOLKE, C., GORDON, L., MOLINA, M., RAMANATHAN, V., ROCKSTRÖM, J., SCHEFFER, M., SCHELLNHUBER, H. J. \& SVEDIN, U. (2011): The Anthropocene: From global change to planetary stewardship. In: Ambio, 40(7), pp. 739-761.

STEFFEN, W., ROCKSTRÖM, J. \& COSTANZA, R. (2011): How defining planetary boundaries can transform our approach to growth. In: Solutions, 2(3), pp. 59-65.

UBA (GERMAN FEDERAL ENVIRONMENTAL AGENCY) (2011): Geo-engineering wirksamer klimaschutz oder größenwahn? Methoden - rechtliche rahmenbedingungen umweltpolitische forderungen. Dessau and Berlin. [online] [Retrieved August 28, 2020] Available at: https://www.umweltbundesamt.de/publikationen/geo-engineering-wirksamerklimaschutz-groessenwahn 
WALBY, S., ARMSTRONG, J. \& STRID, S. (2012): Intersectionality: Multiple inequalities in social theory. In: Sociology, 46(2), pp. 224-240.

WARREN, K. J. (2015): Feminist environmental philosophy. In: E. N. Zalta (ed.): The Stanford Encyclopedia of Philosophy (Summer 2015 Edition). [online] [Retrieved August 28, 2020] Available at: https://plato.stanford.edu/entries/feminism-environmental/

WBCSD (WORLD BUSINESS COUNCIL FOR SUSTAINABLE DEVELOPMENT) (2010): Vision 2050. The new agenda for business. [online] [Retrieved September 11, 2020] Available at: https://www.wbcsd.org/Overview/About-us/Vision2050/Resources/Vision-2050-The-newagenda-for-business

WBGU (GERMAN ADVISORY COUNCIL ON GLOBAL CHANGE) (2011): World in transition: A social contract for sustainability. Berlin: WBGU. [online] [Retrieved August 28, 2020] Available at: https://www.wbgu.de/en/publications/publication/world-in-transition-asocial-contract-for-sustainability\#section-downloads

WEBER, M. (1904/1949): 'Objectivity' in social science and social policy. In: E. Shils \& H. Finch (eds.): The methodology of the social sciences. New York: Free Press, pp. 50-112.

WIERTZ, T. (2016): Technology and politics in the Anthropocene: Visions of solar radiation management. In: S. O'Lear \& S. Dalby (eds.): Reframing climate change: Constructing an ecological geopolitics. London: Routledge, pp. 116-131

WISSEN, M. (2016): Jenseits der carbon democracy. Zur Demokratisierung der gesellschaftlichen Naturverhältnisse. In: A. Demirovic (ed.): Transformation der Demokratiedemokratische Transformation. Münster: Westfälisches Dampfboot, pp. 48-66.

WISSEN, M. (2012): Menschheitsproblem oder Verteilungsfrage? Ein macht- und herrschaftskritischer Zugang zur ökologischen Krise. In: E. Kreisky, L. Löffler \& G. Spitaler (eds.): Theoriearbeit in der Politikwissenschaft. Wien: Facultas, pp. 231-243.

WISSEN, M. \& BRAND, U. (2018): Imperial mode of living. In: Krisis: Journal for Contemporary Philosophy, No. 2. [online] [Retrieved August 28, 2020] Available at: krisis.eu/imperial-mode-of-living/ 